\title{
Protection of Journalists in Armed Conflicts: An International Law Perspective
}

\author{
R. M. T. S. K. Rathnayake* \\ Faculty of Law, General Sir John Kotelawala Defense University, \\ Ratmalana, Sri Lanka
}

\section{Abstract}

Each year a large number of journalists are killed or wounded in armed conflicts. In armed conflicts, journalists are among a precious few remaining actors capable of exposing illegality (Saul, 2009). Because war journalists ensure the realization of the human right to information of citizens all over the world, they play an essential role. International humanitarian law lays down the main international legal framework governing the journalists in armed conflicts. Article 79 of Additional Protocol I of Geneva Conventions states that "Journalists engaged in dangerous professional missions in areas of armed conflict shall be considered as civilians and they shall be protected as such under the Conventions and this Protocol, provided that they take no action adversely affecting their status as civilians". It can be identified that journalists are protected under the condition that they take no active participation in hostilities. However, Geneva conventions have failed to provide a definition or direct participation of hostilities. Therefore, it is not clear of the instances journalists are protected under International Humanitarian Law because protection of journalists depends on the activities of journalists and whether it amounts to a direct participation in hostilities.

Moreover, it can be seen that Geneva Conventions have not addressed the protection of journalists in non-international armed

* Correspondence should be addressed to R.M.T.S.K. Rathnayake Email: thilini4sr@yahoo.com

https://orcid.org/0000-0001-7718-2154

(Received 22nd October 2017; Revised 11 $11^{\text {th }}$ November 2017; Accepted 14 ${ }^{\text {th }}$ November 2017) (C) OUSL 
conflicts. Therefore, journalists in internal armed conflicts are not protected under Geneva conventions. Another, fundamental issue with regard to the protection of journalists is the distinction between War Correspondents and Independent Journalists. It can be identified that Geneva Conventions identifies War Correspondents and Independent Journalists as two distinct categories. Article 79(2) states that journalists should be protected without prejudice to the rights of war correspondents. It is important to identify different types of journalists in order to provide effective protection because different types of journalists serve different tasks in the battlefield and they must be given protection after considering the nature of their journalist activities. In this backdrop, the research aims to identify the existing legal framework governing journalists, to analyze inadequacy of the existing laws to protect journalists and to recommend a suitable protection mechanism to protect journalists. The research follows a qualitative approach of legal research. The research adopts the "Black-letter approach" which resulted in analyzing primary and secondary sources of law. The research recommends the adopting of a separate legal instrument to govern journalists in armed conflicts. An International convention should be introduced to protect them.

Key words: Journalists, War Correspondents, Direct Participation in hostilities

\section{Introduction}

"Journalists are extremely useful as part of the machinery which ensures the implementation of the rules of war when most other means of enforcement are lacking ... It is often through the reports of journalists that inhuman practices in wars are made known to the rest of the world and their function of transmitting news to those outside a particular conflict may be conducive to the condemnation by world opinion of certain methods of warfare or a certain state of affairs (Detter, 2000)"

Media personnel play an important role in armed conflicts. They act as a bridge between the outside world and the conflict area. They provide information to the world that cannot be obtained by any other means. A "journalist" can be defined as "any correspondent, reporter, photographer, and their technical film, 
radio, and television assistants that are ordinarily engaged in any of these activities as their principal occupation (draft United Nations International Convention on the Protection of Journalists Engaged in Dangerous Missions in Areas of Armed Conflict, 1975). War journalists can be considered as "international watch dogs" as they report the real situation of armed conflicts. War journalists are spectators objectively trying to report on a conflict. By definition, war journalists often find themselves in life threatening situations (Fornier, 2014). However, it can be seen that they are incidents of deliberate targeting, which have the aim of discouraging war journalists to exercise their profession. War journalists are not always a wanted spectator and often have to deal with threats against themselves or their relatives or with actual attacks (Rubin, 2013). These targeted attacks come in different shapes, such as targeted killings, arbitrary detention or kidnapping, governmental prosecutions based on rigorous laws on the media or anti-terrorism laws, etc. Also, journalists' possessions, such as filmed material and cameras, may also be confiscated or destroyed as a measure of control or frightfulness (Fournier, 2014). Since 1992, 519 journalists have been killed during war coverage and as of 2016, 259 journalists are imprisoned. Detained journalists illustrate the larger picture of a problematic freedom of expression. Furthermore, it can be seen that with the development of the technology, new harmful weapons are being used and as a result of this it is more difficult for journalists to stay safe in conflicts. Therefore, it is highly important to protect journalists under the international law for them to do their job effectively.

\section{Existing International Legal Framework}

\section{Geneva Conventions and Additional Protocols}

The main law governing the journalists in armed conflicts is the International Humanitarian Law (IHL). General protective principles and the protection of journalists are part of the jus in bello or IHL, which comprises a set of rules 'designed to regulate the treatment of the individual, civilian or military, wounded or active' in armed conflicts. IHL applies the principle of distinction and hence protects combatants and civilians differently (Düsterhöft, 2013).

Article 79 of the Additional Protocol I of Geneva Conventions states that "Journalists engaged in dangerous professional missions in 
areas of armed conflict shall be considered as civilians within the meaning of Article 50 and they shall be protected as such under the Conventions and this Protocol, provided that they take no action adversely affecting their status as civilians, and without prejudice to the right of war correspondents accredited to the armed forces. Moreover, Article 79 facilitates for obtaining an identity card by the government of the State of which the Journalist is a national or in whose territory he resides or in which the news medium employing him is located.

It is clear from Article 79 that journalists are entitled to the same protection as civilians. Therefore, journalists are also protected under Article $51^{1}$ and Article 572 of Additional Protocol I and Geneva Convention IV which specifically focus on civilians.

It is clear that journalists have to remain as neutral persons and they lose protection under IHL if they directly take part in hostilities. However, it can be identified that nor Geneva Conventions (GCs) neither Additional Protocols (APs) provide a definition for "journalist" and "direct participation in hostilities".

1 1. The civilian population and individual civilians shall enjoy general protection against dangers arising from military operations. To give effect to this protection, the following rules, which are additional to other applicable rules of international law, shall be observed in all circumstances.

2. The civilian population as such, as well as individual civilians, shall not be the object of attack. Acts or threats of violence the primary purpose of which is to spread terror among the civilian population are prohibited.

3. Civilians shall enjoy the protection afforded by this section, unless and for such time as they take a direct part in hostilities.

4. Indiscriminate attacks are prohibited.

2 1. In the conduct of military operations, constant care shall be taken to spare the civilian population, civilians and civilian objects.

3. When a choice is possible between several military objectives for obtaining a similar military advantage, the objective to be selected shall be that the attack on which may be expected to cause the least danger to civilian lives and to civilian objects.

4. In the conduct of military operations at sea or in the air, each Party to the conflict shall, in conformity with its rights and duties under the rules of international law applicable in armed conflict, take all reasonable precautions to avoid losses of civilian lives and damage to civilian objects. 5. No provision of this article may be construed as authorizing any attacks against the civilian population, civilians or civilian objects. 
Moreover, it can be seen that in today's world civilians are also actively engaged in media. Lack of a definition for journalist results in difficulties in distinguishing between media-active civilians and journalists (Düsterhöft, 2013). It is important to differentiate between these two categories because journalists have undertaken a duty to report and on the other hand media active civilians are not under such a duty and their activities may differ from the activities of journalists.

It can be identified that AP II and Common Article 3 is silent as to the protection of journalists in non-international armed conflicts (NIACs). It can be argued that as GCs and its APs are considered as 'hard law' which is legally binding, failure to include provisions for the protection of journalists in non-international armed conflicts is another drawback of GCs. As Article 79 of Additional Protocol I covers only the International Armed Conflicts, journalists are not protected adequately in non-international armed conflicts.

It is important to distinguish between war correspondents and independent journalists. War correspondents are defined as 'specialized journalists who are present, with the authorization and under the protection of the armed forces of a belligerent, on the theatre of operations and whose mission is to provide information on events relating to ongoing hostilities' by the Dictionnaire de droit international public. This definition is similar to that adopted in the United Nations Security Council's ('UNSC') Resolution 1738 and also mentioned in the Green Book of the British Armed Forces, specifically emphasizing the need for accreditation (Düsterhöft, 2013). It is clear from the definition that war correspondents are protected by armed forces whereas independent journalists are not under such a special protection.

Overall, it appears that neither independent nor accredited journalists are afforded special status considering the dangerous nature of their work. Instead, journalists are civilians in the event of attacks in both IACs and NIACs. Although IHL does not define journalists or categories thereof, it distinguishes between war correspondents and independent journalists in case of arrest. While independent journalists remain civilians, and are 'solely' afforded the protection of Article 75 AP I, Common Article 3 GCs and generally GC IV, war correspondents (including embedded journalists) are specifically mentioned in GC III and are protected by Prisoners of War (POW) status as persons accompanying the 
military. Therefore, it can be argued that war correspondents are better protected than independent journalists which creates an unfavorable situation for independent journalists because war correspondents by accompanying the military, are likely to have access to significantly more (sensitive) information about the armed forces they accompany than ordinary civilians not connected to the military. Prisoners of war cannot be compelled to answer during questioning and cannot be accused of being spies, their capture must further be notified to the relevant authorities and their families, which means they cannot be held without contact to the outside world (Stolte, 2015).

Another major issue is the term Direct Participation in Hostilities. According to the Additional Protocol I, journalists are protected as civilians unless they take directly participate in hostilities. The legal protection available to them may however be compromised where journalists are deemed to be 'directly participating' in the hostilities. In this situation journalists will be deemed to be making a direct contribution to the fighting and will therefore become legitimate targets under international law. Obviously, the consequences of such an assessment are far reaching, yet there is no clear definition of 'direct participation' in hostilities. Journalists' 'ordinary' professional activities are covered by the international framework and cannot be considered to constitute hostile acts which compromise their civilian status resulting in the loss of protection under IHL. Yet there is also consensus that under certain circumstances the media can be considered to be directly participating in the hostilities (Stolte, 2015). Therefore, it is a major loophole in Geneva Conventions that a definition for the term "direct participation" is not provided. It is clear from all the above arguments that the existing international legal framework is not adequate to protect journalists and this has resulted in major human rights violations of journalists.

\section{Customary International Law}

The customary International Law, Rule 6 states that "Civilians are protected against attack unless and for such time as they take a direct part in hostilities". Moreover, Rule 34 states that "Civilian journalists engaged in professional missions in areas of armed conflict must be respected and protected as long as they are not taking direct part in hostilities. These norms of customary international law apply to both international and non- 
international armed conflicts. Therefore, it can be identified that journalists in NIACs are also protected as civilians. However, it can be argued that the protection awarded to journalists under customary International Law is also based on the civilian protection and they have not been identified as a separate group having special status. It can be argued that equating journalists to 'ordinary' civilians, in terms of required protection under international law both ignores their function and their behavior in conflict zones. As acknowledged by the commentary on Protocol I "The circumstances of armed conflict expose journalists exercising their profession in such a situation to dangers which often exceed the level of danger normally encountered by civilians (Gasser, 1987)." Journalists are more likely to run towards the fighting than away from it, they have generally no interest in being removed from the conflict and seek to access areas ordinary civilians will often have no interest in accessing. Furthermore, they are likely to collect large amounts of information, potentially from both sides of the conflict, which can be seen as suspicious behavior by local authorities and combatants (Stolte, 2015).

\section{United Nations Resolutions}

United Nations Security Council in its $7450^{\text {th }}$ meeting adopted Resolution 2222 on the protection of media professionals in conflict zones on 27 May 2015. The Resolution stresses to promote and protect human rights, and the protection of civilians, including journalists, media professionals, and associated personnel including through monitoring and reporting on violations and abuses as well as providing support for national governments' efforts to promote and protect human rights, and in order to strengthen the fight against impunity for crimes committed against civilians, including journalists, media professionals, and associated personnel. However, it can be argued that as resolutions are considered as "soft law", their binding force upon states are low and not very effective in protecting journalists and the resolution on protection of media professionals in conflict zones is not binding upon states. Moreover, it can be argued that the Resolution is also of the view that categorizing journalists as civilians is sufficient. 


\section{Judicial Decisions}

It can be identified that certain judicial decisions have attempted to fill the gaps in existing laws. It is observed in the research that 'Direct participation' is not laid out clearly in the GCs and APs, but Yves Sandoz et al.'s Commentary on the APs defines it as 'acts of war which by their nature or purpose are likely to cause actual harm to the personnel and equipment of the enemy armed forces', which is reiterated by the ICRC's Interpretative Guidance on the Notion of Direct Participation in Hostilities and includes the taking up of arms, the attempts to capture, to injure or kill enemy forces or to purposefully destroy or damage enemy property and this was expanded it the Targeted Killings case. In the landmark Targeted Killings case, the Supreme Court of Israel concluded that also conduct amounting to, for instance, transporting combatants or weapons, servicing weapons and volunteering as human shields can amount to direct participation. It could be argued that such an expansion is progressive in a context where international law fails to give a proper definition as to what amounts direct participation of hostilities. Therefore, it can be argued that when journalists engage in one or more of the above acts then they can be considered as taking direct participation in hostilities. However, as journalists do not engage in these activities in their ordinary course of business and as they are engaged in war reporting work it can be argued that such a definition of direct participation is not effective.

\section{Recommendations}

In the world, more than 90 percent of crimes against journalists are never prosecuted, are never punished.

Christophe Deloire, Head of Reporters without Borders

It is observed in the paper that protection given to journalists under International Humanitarian Law is inadequate. Also, when identifying the problems in existing legal framework it can be seen that although Article 79 of Additional Protocol states about protection of journalists, it has not provided a definition for them. Lack of a definition for "journalists" has also contributed to result in problems in identifying journalists from other groups of media active personnel. Although, IHL has made a distinction between 
war correspondents and independent journalists, no proper definition is provided. Rule 34 of customary international law states that "Civilian journalists are not to be confused with "war correspondents". The latter are journalists who accompany the armed forces of a State without being members thereof'. It can be argued that such a simple distinction is not sufficient and a proper definition of journalists and types of journalists should be provided in a separate convention. The term Direct Participation in Hostilities (DPH) should be given a proper definition to decide what acts of journalist's amount to DPH. Moreover, it is recommended to protect journalists in IAC and NIAC equally.

It is recommended to introduce a separate legal status for journalists without characterizing them as civilians. Similar to the recognition given to Religious and Medical personnel in the GCs and APs, Journalists should also be given a separate status. IHL distinguishes between combatants and non-combatants. Noncombatants could be again divided to Civilians, Religious and Medical personnel. If journalists are recognized in a separate category, then journalists would also come under the noncombatants in a distinctive group. However, practically in a war zone it is difficult to identify a journalist and therefore, it is recommended to provide them a distinctive emblem to identify them.

Another recommendation is to impose punishments for violating rights of journalists. Geoffrey Robertson, who represented the Washington Post journalist Jonathan Randall at the International Criminal Tribunal for former Yugoslavia (ICTY) in 2003 argues that "deliberate murder of a journalist for reporting in a conflict zone should be a specific war crime. Of course, it is a crime to kill civilians, and journalists count as civilians. But they are not killed because they are civilians but because they are journalists" (The Prosecutor v. Radoslav Brdjanin \& Momir Talic, 2002). Therefore, it could be argued that if killing is made a war crime under the Rome statute, it would reduce the attacks on journalists. However, as the number of state parties who have ratified the Rome statute is low, it is questionable whether the state parties would agree on such an inclusion. However, it could be argued that such an inclusion in the Rome statute would make everyone aware of the importance of journalists and the gravity of the violations of their rights. 


\section{Conclusions}

War reporting is inherently dangerous. Indeed, it could arguably be one of the most dangerous occupations in the world. Still, out of sense of professional duty, many journalists and media professionals make the courageous choice to go to conflict zones, so as to tell the world about the stories of armed conflicts and the human cost they entail (KANG, 2010)

Journalists remain highly vulnerable to serious violence in the course of their professional mission in reporting on armed conflict or other situations of disorder. Although they enjoy a range of protections as civilians in armed conflict, and under international human rights law, attacks on journalists continue, and impunity for those who attack them often remains unaddressed. It is argued in the research that recognizingjournalists as civilians and protecting them under civilians is not adequate given the inherently dangerous nature and importance of their job. The research recommends a separate status given to journalists. Also, making killing journalists a war crime would be a positive step in ensuring their rights.

\section{References}

Kyung-wha Kang, Deputy High Commissioner for Human Rights at the panel discussion on the protection of journalists in armed conflict (14th session of the Human Rights Council, Geneva, 4 June 2010).

Stolte, Y. (2015). The International Legal Framework for the Protection of Journalists in Conflict Zones: A Round Peg in a Square Hole? (Doctoral dissertation, The University of Edinburgh, United Kingdom) Retrieved from: https://www.era.lib.ed.ac.uk/bitstream/handle/1842/10 597/Stolte2015.pdf? sequence $=2$ \&isAllowed $=y$

Saul, B. (2008). The International Protection of Journalists in Armed Conflict and Other Violent Situations. Australian Journal of Human rights.http://www.austlii.edu.au/au/journals/AJHR/200 8/5.pdf. 
Deter, I. (2000). The Law of War. Cambridge, Cambridge University Press.

1975 draft United Nations International Convention on the Protection of Journalists Engaged in Dangerous Missions in Areas of Armed Conflict.

Anon, (2017). [online] Available at: https://cpj.org/reports/CPJ.Pakistan.Roots.of.Impunity.p df [Accessed 29 Sep. 2017].

Düsterhöft, I. (2013). The Protection of Journalists in Armed Conflicts: How Can They Be Better Safeguarded? Utrecht Journal of International and European Law, 29(76), p.4.

Fournier, L. (2014). The Protection of Journalists in Armed Conflict. LLM. Ghent University.

Yadav, S. (2017). Journalist and News Media Personnel in Armed Conflicts: Protection Measures in International Humanitarian Law. [online] Academia.edu. Available at: https://www.academia.edu/3686988/Journalist_and_Ne ws_Media_Personnel_in_Armed_Conflicts_Protection_Meas ures_in_International_Humanitarian_Law [Accessed 29 Sep. 2017].

Public Committee V. Government of Israel HCJ 769/02 (2006).

Resolution on the protection of media professionals in conflict zones UNSC Res 2222 (27 May 2015) UN Doc S/RES/2222. 